So
566
$67 A 4$
1916

Convolidation of Jrest bands in Oregon. 


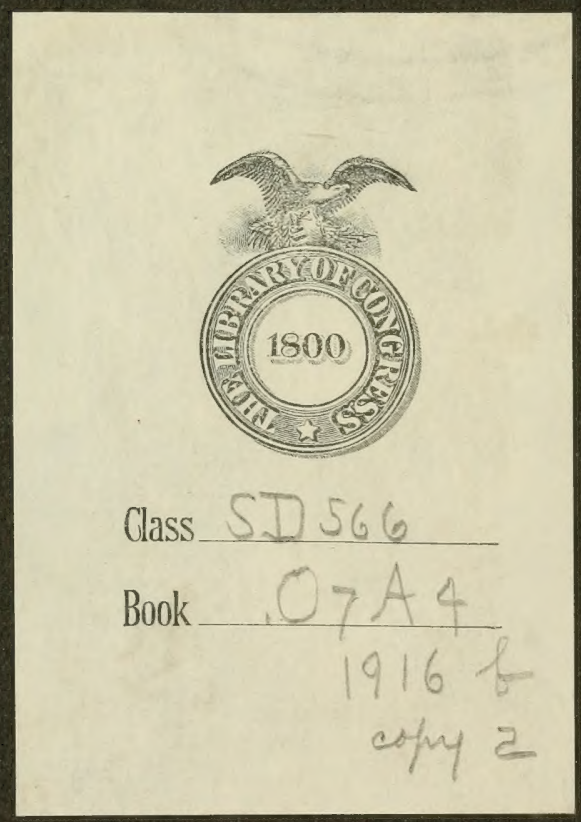




\section{CONSOLIDATION OF FOREST LANDS IN OREGON}

\section{HEARINGS}

BEFORE THE

\section{COMMITTEE ON AGRICULTURE}

4. 8. Cry, HOUSE OF REPRESENTATIVES

SIXTY-FOURTH CONGRESS

First Session

oN

H. R. 13046

FRIDAY, AUGUST 4, 1916

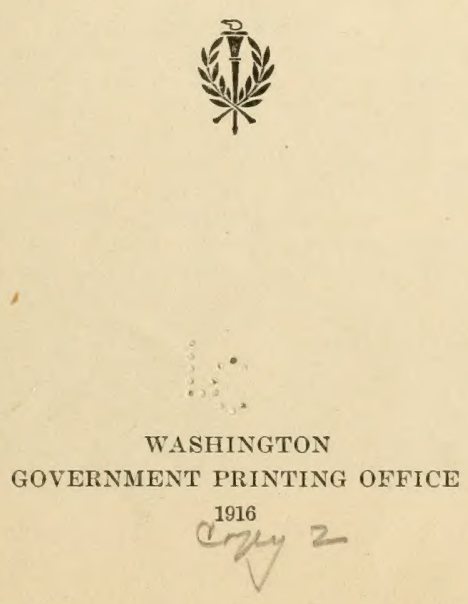




$$
\begin{aligned}
& 51566 \\
& 10744 \\
& 1916 b 5 \\
& \text { cop } 2
\end{aligned}
$$

D. of D.

SEP $\quad 9 \quad 1916$ 


\title{
CONSOLIDATION OF FOREST LANDS IN OREGON.
}

\author{
Committee on Agriculture, \\ House of Representatives, \\ Friday, August 4, 1916.
}

The committee met at 10.30 o'clock a. m., Hon. Asbury F. Lever (chairman) presiding.

The Charrman. The committee will come to order. Gentlemen, we have met this morning to take up again House bill 13046, a bill to consolidate certain forest lands in the Oregon National Forest, in the State of Oregon. By direction of the committee, I referred that bill to the Secretary of Agriculture for report and have this morning received his report. I will ask that the clerk read his report and that it be made a part of the record.

(Said report follows.),

Hon. A. F. LEVER,

House of Representatives.

DeAR Mr. Lever: Receipt is acknowledged of your request for a report on bill H. R. 13046 to consolidate certain forest lands in the Oregon National Forest, in the State of Oregon. It is understood that your committee also wishes a full explanation of the procedure followed in effecting such exchanges.

This bill proposes that for the purpose of consolidating forest lands belonging to the United States within the Oregon National Forest, the Secretary of the Interior be authorized, upon the recommendation of the Secretary of Agriculture, to exchange upon the basis of equal value lands belonging to the United States in national forests in the State of Oregon for privately owned land lying within the exterior boundaries of the Oregon National Forest. Upon the consummation of any such exchange the lands deeded to the United States shall become parts of the Oregon National Forest.

Section 2 of this measure apprpriates $\$ 6,000$ for the purpose of carrying out the provisions of section 1 .

The immediate reason for suggesting the introduction of this bill was to make it possible for the Federal Government to obtain conveyance of title to private lands in that part of the Oregon National Forest forming the original Bull Run Forest Reserve and embracing the source of the water supply of the city of Portland.

The Bull Run Forest Reserve was established by proclamation of the President, dated June 17, 1892, under authority of the act of March 3, 1891, entitled "An act to repeal timber culture laws, and for other purposes.'

In order to obtain full protection of the source of the water supply of the city, Congress passed the act of April 28, 1904 (33 Stat., 526). This act provides a penalty for trespass on these lands by anyone other than Government officers and certain officials of the State. In administering the Oregon National Forest this department has endeavored to carry out the clear intent of Congress to maintain the purity of the municipal water supply by preventing the use of the land within the Bull Run division in any way which might pollute the water.

It appears, from the records of this department, that there were $21,422.11$ acres held in private ownership within the Bull Run division of the Oregon National Forest. There were 10,706.47 acres of land within the grant to the O. \& C. Railroad Co. The title to these lands has been revested in the United States under the provisions of section 1 of the act of June 9,1916, Public, 86. This leaves $10,715.64$ acres of privately owned land within the Bull Run division. Of this amount, however, 2,068.6 acres have been acquired by the city of Portland, leaving a total of 8,647.04 acres of land on this watershed not in public ownership. These lands are distributed among 25 owners, the most extensive holdings being those of the Bridal Veil Lumber Co. (owning 
about 2,600 acres), the Crown Ca'ifornia Fu'p \& Faper Co. (owning about 800 acres). IV. E. Goodfellow (owning about 1,2s0 acres), while the baiance is distributed in small lots ranging from 40 a res upward.

The officers of this department have been working in harmony with the municipal officials who have been endeavoring to ascertain the attitude of the owners of these private lands toward an exchange of their holdings within the Oregon National Forest for lands not on this drainage area. Most of these owners have expressed a willingness to consummate such an exchange. Some desire that the exchange shall be of lands of equal value, while others have indicated a preference for selecting national forest timber of equal value to the lands reconveyed.

Considering the purpose for which the Bull Run Forest Reserve was established, and the present administration of this area to protect the municipal water supply of the city of Portland, this department would approved of eliminating the titles held in private ownership. Since some of those desiring to exchange would prefer timber to lands your committee may wish to insert the word "land" in line 8, page 1 of the bill, the words "or timber." "This recommendation has already been submitted to the Senate Committee on Agriculture which has under consideration bill S. 5515 , the terms of which are identical with those of the measure before your committee.

The desirability of obtaining public control of all the lands embraced in this watershed requires little explanation or argument. The lands are all heavily timbered and if left in private ownership this timber will ultimately be cut and the slashings left without protection from fire. It is desirable to maintain the uniformity of the forest cover in order to regulate the water flow and maintain a supply at full volume and highest palatability. In addition, it is desirable to exclude human habitations and all domestic animals from the area in order the protect the water from danger of pollution. The security of the health of 300,000 people, whose lives might be menaced by the pollution of their drinking water at its source, far outweighs consideration of volume of supply or the immediate utilization of the relatively small amount of timber involved. Unquestionably, the highest use to which this land may be put is that of furnishing a pure supply of water for human consumption.

The general features of this measure have a great many legislative precedents. General exchange bills for the following national forests have already received legislative sanction: Kansas National Forest, Paulina National Forest, Ochoco National Forest, and Florida National Forest. In addition, a number of special exchanges have been authorized by Congress. At the present time there is pending before the House a measure authorizing the exchange of Government timber for privately owned land in the Whitman National Forest, which measure has been favorably reported by the Public Lands Committee of the House; and, finally, the Senate has passed a general measure authorizing exchanges of this nature involving privately owned land in any of the national forests in the United States.

Some inquiries have been made regarding the procedure followed by the Forest Service in consummating exchanges of this nature, after legislative authority is granted. The initial step will be for the private owner to submit an application, expressing his willingness to effect an exchange, giving a description of his privately owned land by legal subdivisions and stating the area of Government land which he desires to select in exchange. A preliminary report is made by the forest supervisor, or by his deputy or a forest examiner under his direction, and if from this report it appears that such an exchange would not be in the interests of the public, even in the event that the values are found to be equal, the application is rejected and the applicant is advised of the reason it is not considered desirable to consummate the exchange. The applicant may then amend his application by applying for Government land so located or of such a character that an exchange would be in the public interest. If the supervisor's report upon the amended application indicates that the exchange would be desirable, the district forester then directs that a valuation survey be made covering the private land offered in exchange and the Government land applied for.

Such a survey requires the accurate location of the land, a careful cruise of the timber, and the preparation of a topographic map and descriptive report. The report must show by legal subdivisions the amount, character, and sale value of merchantable saw timber by species, the amount of cordwood material, and the amount, age, character, and condition of reproduction, elevation, and character of the topography, and character of soil. It must show the value of the timber by thousand feet board measure, the value of the cordwood per cord, and the desirability of the young species from a silvicultural standpoint. It must also show the general productive capacity of the land as a timber-producing area, together with the favorable or unfavorable characteristics of topography or location which may affect valuations. In the report upon the privately owned land offered in exchange, the valuation survey will 
show what administrative or other public advantages will be gained by the proposed transfer, what obstructions to efficient protection and utilization will be removed by such a consolidation, together with the objectionable features to the exchange itself, if any appear.

Conversely, the report upon the Government land applied for in exchange will cover the same points, which report contains a final summation of values, together with final recommendations. The final recommendation is not necessarily a "yes' or "no" decision upon the applications, but is usually a constructive solution of the exchange problem, the recommendation stating that certain enumerated subdivisions of Government land applied for have been found to be of equal value to the privately owned land offered in exchange, that an exchange upon such a basis would be desirable, and that the applicant should be advised that his application must be rejected as to the remaining areas before a favorable consideration will be given to an exchange.

Where the area involved is small and the work can be done with the regular force without additional assistance, the valuation survey is usually made by the forest supervisor, a deputy supervisar, or forest examiner, all experienced men. This report must receive the approval of the forest supervisor and is then transmitted to the district office where it is checked by the logging engineer and the assistant district forester in charge of timber sales. If the values are considerable, or these officers are not personally familiar with the region. a field check will be ordered before the exchange rechange receives the approval of the district forester. This check will be made preferably by the logging engineer assigned to that district, or some other lumbermen or cruisers of known still and integrity. All large exchanges are handled more directly from the office of the district forester. The cruisers are specialists attached to the district organization, and all estimates are checked for the accuracy of the cruise and valuations either by the logging engineer or one of his assistants.

If the exchange receives the final approval of the district forester, the entire record, including the maps and reports, is transmitted to the Forester at Washington, D. C. Here they are again carefully checked by the four administrative branches of silverculture, operation, lands, and grazing, and if approved by them and the Forester, the entire record is then transmitted to my office with a draft of a letter to the Secretary of the Interior recommending that he accept reconveyance of the certain described privately owned lands, provided satisfactory title be shown, and that in lieu thereof certain other described Government lands which have been examined by this department and found to be of equal value to the reconveyed lands be patented to the applicant.

The Department of the Interior passes upon the sufficiency of title before such reconveyance is accepted. Upon the acceptance of reconveyance, patent is issued to the area selected, all parties are notified and the exchange is complete and permanent.

This department has uniformly favored exchanges upon the basis of equal value such exchanges would be desirable from a public standpoint. In land exchange . pi is ls due weight has uniformly been given to the amount and character of timber, the character and productive quality of the land, together with its location and the surroundings influencing the value of its production. But we have not placed a valuation upon the removal of an administrative interference, nor have we allowed the private owner to capitalize the dangers of a public menace. It has been the belief of this department that neither the Government nor the private owner can advantageously capitalize the inconvenience resulting to either party because of the presence of land owned by the other. Such inconvenience is not a "value" to be expressed in terms of dollars and cents, but is instead an injury to be avoided, and is, in fact, the very element which induces both parties to desire an exchange. Usually the inconvenience to one party is as great as the inconvenience to the other, but even when one party is very materially the sufferer, no attempt has been made to equalize the situation by placing an increased money value upon the lands of the other.

In accordance with this policy, the department has not considered the influence of a tract of land upon the desirability of a watershed as a "value" which might be advantageously capitalized in considering a land exchange, although it may have important public consideration which justifies the exchange. Such influence is an element from which the private owner himself could never realize the slightest direct monetary return. The presence of a typhoid patient on a tract of privately owned land within the watershed utilized by a municipality might result in incalculable injury to the public, but by no possible means could it result in profit to the individual owner. The presence of slash on logged-off private land intermingled with stands of valuable Government timber might result in grave injury to public property, but that injury could not result in profit to the individual, and therefore the danger of that injury should not be capitalized in considering the value of such private holdings. 
Accordingly, for the purposes of land exchange appraisals, this department has considered only such elements as actually enter into commercial transferable values. To attempt to include more intangible factors might not only lead us into absurdities, but might even result in the equivalent of public blackmail. Nor has it been necessary to take such factors into consideration in order to effect exchanges advantageous to the private owner as well as to the public. Such consolidations usually result in increased value to both parties and are consequently mutually profitable.

The department therefore recommends that this measure receive your favorable consideration.

Very truly, yours,

D. F. Houston, Secretary.

The Chairman. We have present this morning gentlemen from the Forest Service, and if any member of the committee desires to ask any questions of these gentlemen he may do so. I will ask Mr. Potter to answer such questions as may be asked or have his associates do so.

$\mathrm{Mr}$. Anderson. I would like to ask one question.

The Chairman. All right.

\section{STATEMENT OF MR. ALBERT F. POTTER, ASSOCIATE FORESTER, DEPARTMENT OF AGRICULTURE.}

Mr. Anderson. How will these exchanges be effected where an exchange is proposed of timber for land and timber?

Mr. PotTer. That would always be in a case where the land and timber were owned by a private party who desired to exchange them for Government timber. In that event a valuation would be placed upon the land separate from the timber. For example, if the land only had a value for timber production the base value might be considered to be $\$ 3$ an acre; if it also had a value for grazing the base value might be considered to be $\$ 5$ an acre, and if it had a value for farming the base value would probably be considered to be as high as $\$ 10$ an acre. That value would be added to the appraised value of the timber in accordance with the number of thousand feet that were upon the land. Then the sum of those two values would be equalized by a body of timber on Government land which had in itself a value equal to the value of the combined land and timber values on the private lands.

In the exchanges which are pending with the States of Idaho, Montana and Washington we have found, in all three inctances, that the States desired to select, as land which will be retained by the States, an area which has an average timber stand greater than the stand of timber on their scattered sixteens and thirty-sixes, and in order to bring about those exchanges it will be necessary for us to allow the States to take, for example, in exchange for 250,000 acres of school lands a tract of 150,000 acres of timberland, which 150,000 acres will contain as much timber as there is on the entire 250,000 acres of State lands. Then the State will take 100,000 acres of nontimbered land, which will equalize the value. So that the State, on the whole, will get the same amount of timber and will give the same acreage of land that it gets, but the timber land that it gets will average higher in value than the timber land that it gives, although the total value of both the land and timber will be the same. We will have to adjust all three of those State exchanges in that way, that is, by giving them an area of timber land which will carry a heavier stand per acre than the average on the State lands, and then equalize 
it by getting them to take the residue in nontimbered land, which would only have a base value.

Mr. Haugen. Are the differences in value always adjusted?

Mr. PotTer. They are always adjusted through a selection of land which, as a whole, would be equal in value.

Mr. Haugen. For instance, one section is to be exchanged for another section, and there could be a thousand dollars difference in value. In that event, how is that adjusted-simply by finding some more land?

Mr. Potter. No; the exchange, in that event, would not be made unless the values were approximately equal.

Mr. Hawley. And unless the party who wanted to make the exchange was willing to take a less acreage?

Mr. Potter. Yes, sir.

Mr. Helgesen. For the purpose of illustration, let us take a cutover piece of land. In most instances, such a piece of land is practically valueless, is it not?

Mr. Potter. It only has what we call a base value; it would not be worth, probably, over $\$ 2$ or $\$ 3$ an acre-that is, if it is only suitable for timber. If it is suitable for farming, then it would have a higher value.

Mr. Helgesen. If you trade for a cut-over piece of land and pay for it in Government timber, then the Government will be getting that cut-over piece of land instead of valuable timber, will it not?

Mr. PotTer. Yes; it would, and the kind of a trade that would be made in that event would be that if we placed a base value of $\$ 2$ an acre on a section of land of that kind it would mean that we considered that section worth $\$ 1,280$ for the purpose of growing timber, and we would give for such a section $\$ 1,280$ worth of timber upon its appraised stumpage value.

Mr. Helgesen. That is a very nice proposition for a private owner who wants to dispose of that kind of land, but I do not see wherein the Government gets any particular value.

$\mathrm{Mr}$. Poтter. It gets value by getting land that is suitable for the production of timber, and on which it can afford to raise timber.

Mr. Steele. Your object is to solidify it?

Mr. Potter. Yes; and it also solidifies the ownership so that it simplifies administration by the Government.

Mr. Hawley. But that particular question would not come up in this proposed exchange. The only object here is to eliminate private owners from the watershed of a great city's water supply. That is the purpose of this bill, to prevent contamination of a great city's water supply and to protect the health of the city by eliminating private ownership from about 8,600 acres in the Bull Run watershed and giving them lands outside of that watershed. It is practically the same kind of country all through there.

Mr. Steele. From your statement it would appear that your answer was that you are trading for cut-over lands and giving timberlands in exchange; but that is not true unless it is beneficial to the Government.

Mr. Potter. No, sir; not unless it is beneficial to the Government. As a rule, the majority of the land is not of that character, although sometimes there are tracts of cut-over lands included in the exchanges. That, of course, is bound to happen in our exchanges with the States, 
because some of the school lands have been cut over. In that event we must only consider the base value - that is, what the land itself is worth-and give the State that value in return.

Mr. Helgesen. Is it anticipated that there would be an $y$ such exchanges under this particular bill ?

Mr. Potter. It would be possible to make such an exchange under the wording of the bill; yes, sir.

Mr. Anderson. Under the wording of the bill as it was introduced?

Mr. Potter. Yes, sir.

Mr. Haugen. In exchanging a one-half section for another half section, suppose it were found that the section in the forest owned by the Government is worth, say, $\$ 1,000$ more than the other half-section, how are you going to adjust that difference?

Mr. PotTer. We can adjust that difference only by adding a few acres.

Mr. Haugex. By adding a few sections?

Mr. Potter. By adding a few acres to the tract.

Mr. Haugen. And thus making up the difference?

Mr. Potter. Yes.

Mr. Haugen. And only in that way can it be adjusted?

$\mathrm{Mr}$. Potter. Yes. That is one of the reasons for suggesting that possibly the committee would desire to include the words "or timber," so that in the event the land values were different we might adjust them with timber without having a difference in the acreage.

Mr. HAUGEN. In adjusting or appraising the values of these lands are the interests of the Government safeguarded in every instance?

Mr. Potter. Yes, sir. We only consider exchanges when it will be advantageous to the Government to make them; we have never favored exchanges that were to be made merely for the convenience of the private owner, but it is always when we consider that it will be a benefit to the public. In this case, of course, it will be of special benefit to the city of Portland.

Mr. Anderson. I understand that that is the first question to determine, that if it is not determined that the exchange is advantageous in the first instance the proposition does not go any further.

Mr. Potter. We would not consider it at all.

Mr. Haugen. Now with reference to the cruises. How are the cruisers appointed?

Mr. Potter. Mr. Chairman, I would like very much to have you hear Mr. Greeley as to how the cruises are made, as well as the appraisals. That work is under Mr. Greeley's direction, and I know that he can answer the questions asked in reference to every datail.

\section{STATEMENT OF MR. W. B. GREELEY, ASSISTANT FORESTER, IN CHARGE OF SILVICULTURE, DEPARTMENT OF ARGI- CULTURE.}

Mr. Haugen. I would like to have you make it clear that the interests of the Government are safeguarded in every move made.

Mr. Greeley. These cruises are made, in the first instance, by experienced woodsmen who have had from six to eight years practical experience in the identical region. Their cruises are checked by lumbermen who are all men of practical experience in lumbering and wood estimating in the several regions, and who are the most competent men in our organization. 
Mr. Aruenson. Let me ask you a question, berause I want to eret this clear in my mind. When rou speak of eruisers do you mean men who are regularly and permanently employed by the Government?

Mr. Greeler. In nearly erery case; yes, sir. 'They are permanent employees.

Mr. Andersox. When you speak of lumbermen what do you mean?

Mr. Greeler. The lumbermen are also permanent employees of the Forest Service. They are engaged on that class of work and selected for their caparity in that particular line. For example, in this particular region

Mr. Hitaex (interposing). How is their anpacity for this work determined?

Mr. Grencer. They are selected, in the first instance, through competitive examination; then they are tried out, and if they make good they are assigned to that elass of work. "Then they build up through continued experience.

Mr. H.wLer. The parties rou have out there appratising timber have the henefit of practical experience in that section of the country all the time?

Mr. Greeler. Yes, sir. In this instance in Oregon, for example, we hate a lumberman who has had some 1.5 years of practical experience in the lumber industry in that region and who has been in our employ for upward of 12 years. He is one of the most competent lumbermen in that region. A check is always required on every exchange about which there is the slightest question, a personal examination and cherk of both the quantity of timber and of the ralue placed upon it.

The CHaIruax. Is there any thing further, gentlemen?

Mr. Haugex. I think the letter from the department explains the matter very well.

Mr. Greerey. I wolidd like to suggest, Mr. Chatiman, that I hare here a copr of an appratial made of a tract of timber which happens to aljoin the Bull Run watreshed, which will indicate to the committee, if you c:res to incorporate it in the record, just how the ralues are arrived at. It will show the detail into which our lumbermen go in determining the value of timber.

The Chairin. What about that, gentlomen?

Mr. ReILly. You follow the usual practice, do you not?

Mir. Greeley. Yes, sir.

Mr. HAUgEx. Are there any water powers on any of these lands?

Mr. Greerey. I do not know as to that.

Mr. Hawler. If there are, they would be acquired by the Gorermment, because most of those that would be exchanged are on the watershed, where the strams ar only trickling ones, and the Gorcrmment would get them where the streams liare become of more size.

Mr. Greeler. I think that is the case, although I am not familiar with this particular section.

The Chammax. Suppose you leave that with the committee. bill?

Mr. Hatrex. How many exchanges are contemplated under this

Mr. Greeler. There is just the single proposition in rolred of the holdings of several parties in the Bull Run watershed. 
Mr. Haugen. That takes in the 8,000 acres and 11,000 acres?

Mr. Greeley. I understand so; yes, sir.

Mr. Havgen. About 8,000 acres owned by individuals, 2,000 acres by the city of Portland, and the Government owns about 11,000 nores, I believe the letter states.

Mr. Greeber. The exchange would cover only the $S, 000$ acres owned by indiriduals and not that owned by the city of Portland.

The Chamman. Is there anything further, gentlemen?

Mr. Haugen. Is it necessary to go to that extent?

Mr. Greeley. I do not understand you.

Mr. Haugen. Is it necessary to make all of those exchanges?

Mr. Greener. It is necessary to acquire all of those tracts in order to place the whole watershed under proper supervision.

Mr. Haugen. It was stated the other day that a half section, or possibly one or two nore sections arded to the half section, was all that would be required or all that was contemplated.

Mr. Hawley. That was what was to be immediately dome because of the logging operations.

Mr. Brigas. I intended to make it plain the other day that the half section was the only one in which I was inferested. I did not mean to infer that the Forest. Service did not wish to get other owners as well as ourselves out of the reserve. As far as the city is concerned, the water commissioner told me before I left home that he was very anxious to eliminate all private owners within the reserve. There have been times when hunters, berry pickers, and so on, have gone into the reserve and claimed that they had the right to go in there because of ownership or permission from owners. He said they wanted to eliminate any possible excuse for anybody going within the limits of the reserve.

Mr. Helaesen. Is it contemplated to take orer the 2,000 areres owned by the city of Portland?

Mr. HAwley. Oh, no.

The Cimminas. I would suggest that we print the menorandum that Mr. Groeley has presented to us. It will give us an idea how these exchanges are mate. Without objection that will be done.

(Said memorandum follows:)

\section{Sales, West Fork of Hood River Area, Oregon.}

[Report and appraisal by W. T. Andrews and I, A. Nelson, Jume 1, 1916.]

\section{DESCRIPTION.}

The tract of timber covered by this report and appraisal lies on the watershed of the West Fork of Hood River and tributaries, Iadd, Mc Gee. Elk, and Jones Creeks, Oregon National Forest, Oregon. The area is reached by wagon road and trail from Dee, Oreg., a station on the Mount Hood Railwity, 12 miles south of the town of IIood River, Oreg., on the O. W. R. \& N. Railway. Automobiles can be used a portion of the year for a distance of 6 miles out of Dee; for the remaining 3 miles to the trail it is possible to use wagons. The wagon road continues on to Lost Lake, but it is in very poor condition for wagon traffic. The trail to and through the area is well constructed on a maximum 5 per cent grade. There is a Forest-Service telephone line along this trail in secs, 23 and 35, T. 1 S., R. 8 E., Willamette meridian, of the proposed sale aren.

A portion of the West Fork of Hood River watershed is in the Bull Run Reserve, which was created for the purpose of protecting the water supply of the city of Portland, Oreg. The sections in the reserve bordering on the sale area are secs. 1, 2, and 3 , T. 2 S., R. 8 E., and secs. 22,27 , and 34, T. 1 S., R. 8 E., Willamette meridian. The water supply of Portland is obtained from Bull Run River and tributaries. There is a high divide between the Bull Rum and West Fork IIood River watershed. 
The west boundary of the sale area is from one-half to 2 miles from the summit of this divide. The drainage on the sale area is away from the Bull Run watershed, therefore the logging of the timber can in no way affect the water supply of the city of Portland.

The total area of the West Fork Hood River drainage within the forest boundary is 18,780 acres, made up of the following:

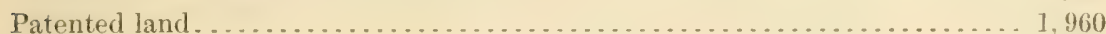

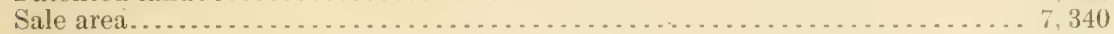

Protection forest . ....................................... 9, 480

The sale area comprises all of secs. $1,2,11,12,14,23,26$, and 35 and portions of

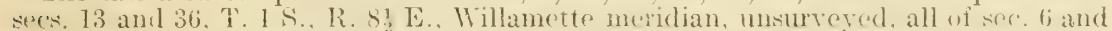
purtions of sees. 5 and 7. T. I S., R. 9 E.. Willamette meridian, unsurvered, all of sec. 23 and portions of secs. $13,14,24,25,26,35$, and 36, T. I S., R. S E., Hillamette meridian, surveyed, a total area of approximately 7,340 acres.

The amount of timber estimated to be on the sale area, by species, and the total amount is as follows:

Douglas fir.

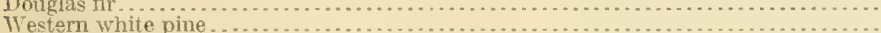

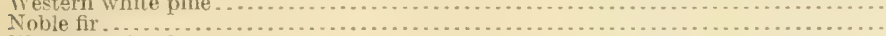

Western red cedar.

TVestern hemlock

Amabilis fir.

Total.

\begin{tabular}{r|r}
258,000 & 71.7 \\
4,000 & 1.1 \\
6,000 & 1.6 \\
9,000 & 2.5 \\
63,000 & 17.5 \\
20,000 & 5.6 \\
\hline 360,000 & 100.0
\end{tabular}

Old cuttings.-There are no old cuttings within the boundaries of the area.

Primul interests.- There are no private interests within the boundaries of the proposed sale area. Portions of secs. 13, 24, 25, 26, 35, and 36, T. 1 S., R. \& E., Willamette meridian, totaling 1,960) areses are batented. I portion of this land is ownerd hy the Oregon Lumber Co. and the rest by individuals. Practically all of the above land lies along the main streams, seldom woing up the slopes any distance. The stand of timber is of a better quality than on the forest. It is extimated the stand of timber on this area is $120,000,000$ feet $\mathrm{b} . \mathrm{m}$. There would seem to be a favorable opportunity

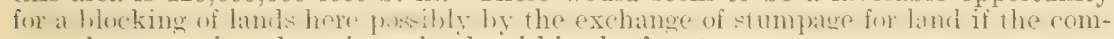
pany later acquires the private lands within the forest.

Timber considercd in the appraisal.-It is estimated that there is approximately $1,000,000,000$ feet of merchantable timber on the West Fork of Hood River and tributaries that will come out over the main line railroad. The estimated amount of timber, private and national forest, embraced in this appraisal is $480,000,000$ feet b. $\mathrm{m}$. In the portion of T. 1 S., R. 8 E. not included in the contemplated sale the amount of merchantable national forest timber is $90,000,000$ feet, and on patented land there is $70,000,000$ feet. The merchantable timber in T. 1 N., R. 8 E. on the national forest is approximately $260,000,000$ feet. Sutside of the fores it is extmater that there is approximately $100,000,000$ feet.

This totals as follows in thousand feet board measure:

\begin{tabular}{|c|c|c|c|c|c|}
\hline Area. & $\begin{array}{l}\text { National } \\
\text { forest } \\
\text { timber } \\
\text { in sale. }\end{array}$ & $\begin{array}{c}\text { Adjacent } \\
\text { national } \\
\text { forest } \\
\text { timber not } \\
\text { in sale. }\end{array}$ & $\begin{array}{c}\text { Private } \\
\text { timber } \\
\text { considered } \\
\text { in ap- } \\
\text { praisal. }\end{array}$ & $\begin{array}{c}\text { Adiacent } \\
\text { Private } \\
\text { timber not } \\
\text { considered } \\
\text { in ap- } \\
\text { praisal. }\end{array}$ & Total. \\
\hline 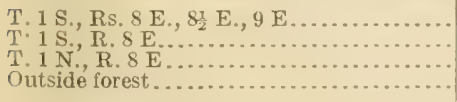 & 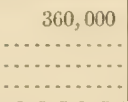 & $\begin{array}{r}90,000 \\
260,000 \\
\ldots \ldots \ldots\end{array}$ & $\begin{array}{r}120,000 \\
\cdots \cdots \\
\cdots \\
\cdots\end{array}$ & $\begin{array}{r}70,000 \\
100,000\end{array}$ & $\begin{array}{l}480,000 \\
160,000 \\
260,000 \\
100,000\end{array}$ \\
\hline Total. & 360,000 & 350,000 & 120,000 & 170,000 & $1,000,000$ \\
\hline
\end{tabular}


Soil.-The soil on the area is a shallow, sandy loam. A few cases occur where it is from 1 to $I_{2}^{1}$ feet deep. Frequently it is almost entirely replaced by broken rock, this latter condition being an important consideration in determining the agricultural value. The poor quality of the silo and the steepness of the slope make the area unsuited for agricultural purposes.

Reproduction.-The reproduction on the area containing merchantable timber is an understory of western hemlock, amabilis fir, and western red cedar, with a small percentage of Douglas fir. For restocking the area it has no value, and no effort shoult be made to protect it during loggine operations. The bumed areats within the sale boundary have resteked fully with Donglas fir, western hemlok, western red cedar, western white pine, and amabilis fir, the first species mentioned predominating. These areats whold be proterted during lewging operatim.

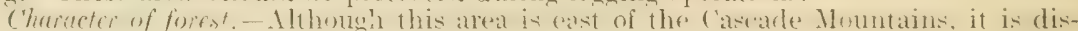
tinctly west-side type, consisting of Douglas fir, western hemlock, amabilis fir, westerm red cestar, noble fir, and western white pine, named in the orrer of their inportance. The area is situated in a bit of country lying on the eastern extrenty of the humid coast region and in the central portion of the Cascade Mountain Range. Therefore the climate is neither humid nor arid.

Douglas fir.-This species comprises 71.7 per cent of the total stand on the sale area. The character and condiion of the stand within the sale boundary are those of a mature, even-aged, irregular in tree diameter and quality and above normal in soundness. The typing of the map is, perhaps, misleading in defining of age classes. Thile there is a wide difference in tree sizes, conservative judgment would define the stand as above. The green timber is untisually sound, in a comparative way, scarcely any trees being totally defective from fungous diseases. It is noted, however. that there is an enormous amount of dead Douglas fir occurring in groups and singles in a more or less regular manner throughout the entire area. This serious deterioration is ascribed to two causes, viz, first, it is believed that climatic conditions is the principal one. From November until May there is an almost incessant fall of rain or snow, while the months of June, July, August, and September are very hot and dry. The second contributing factor is probably poor soil. Where the snow had disappeared it was noted that the surface was very rocky with a mixture of nonporous clay.

It appears that the timber grows very rapidly for about 100 years, lessening greatly with an increased age. There does not appear to be many trees in a suppressed or dying condition, leading to the assumption that deterioration takes place quickly. It is clear that the timber is on the decline in quantity and gaining nothing in quality.

On a numerical basis the stand is about normal. The heaviest stand on this basis occurs in sections 5 and 6 . Here the normal maximum diameter is 34 inches: the trees are tall, straight, with few limbs, but knotty down to the base. On the lower elevations the trees are fewer per acre, larger, and of a better quality. A similar stand, on a numerical basis, in the Pacific coast region, would grade muci lin ir. $i$ ?

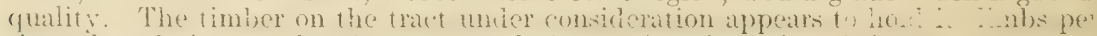
sintsutly. It is true that from a castal observation the boles of the trees alpentr to be clean, but a close inspection reveals small dry limbs and pin knots.

lmalilis fir.- The amahilis fir stand is confind matly to the higher elevations in nearly pure stands alone the south and west sides of the sale boumdary and in an irregular manner over other portions of the area. The trees are tall and shapely, but knotty and for the most part defective.

These species are similar in quality and texture and are suitable for boxes and light dimension.

Western hemlock:-Western hemlock, comprising 17.5 per cent of the estimated stand, occurs over the entire area in mixture with the other species. In places it is found in nearly pure stands. In portions of the area it is of a good size and quality, but as a rule it is rough and defective and will only cut into the lower grades of lumber.

Western red cedar.- The quality of this species averages very low. Here and there there are small groups of and single trees having a short surface-clear log or a surfacerlear side which would gualify as eibher goed shingle tindere or produce a fair percentage of clear lumber. On the whole, however, the timber is knotly, coatre grained, and much of it small. While no doubt the timber woukl protures a fair amount of shingles of the Star grade, it is not believed that this product could meet the competition of the shingles manufactured in the State of Washington.

Noble fir.-This species is tall, shapely, and of good quality, but forming only 1.6 per cent of the stand. It occurs in small bunches generally in the southern portion of the area.

Western white pine.-The small amount of white pine occurs in a scattered manner over the entire area. Tree diameter and quality cover a wide range. There are many fine specimens, 36 to 40 inches in cliameter, apparently in a goorl state of preserva- 
tion. On the other hand there are groups of small, short trees 10 to $16 \mathrm{inc}$ hes in diameter occurring mostly on exposed points, in a dying or decadent condition. In one such place more than one-half of the stand is dead.

Types within west Hood River watershed.-In order to discuss the types of this region to better advantage the area will be divided into two parts, that within and without the sale boundary but in the watershed. Within the sale boundary are found all the age classes of the Douglas fir tye, westem hemlork, mountain hemlork, fir and cedar types.

The Douglas fir type comprises practically the ent ire area within the sale boundary. The two types designated in the may) as the older age classes are of most importanee in point of area covered and stand of timber represented. This lact still holds true when the patented land is not considered. Trees between 20 and 48 inches in diameter have a merchantable length ranging from 70 to 150 feet. The younger age classes are to be found where fire has destroyed the original stand, but these areas are not of great importance.

In mixture with this type are found westem hemlock, western white pine, cedar, and noble fir, in order of their importance. These species form, with a few exceptions, the second story of the forest, and as a rule do not attain a large size nor form a large factor in the stand.

Although considerable western hemlock is scattered over the entire area, in a few cases it is prominent enough to form a type by itself, but the extent of this type is of minor importance. The timber in its own type does not attain a large size; it is limby and rough. The better class of hemlock is found in the Douglas fir type. This is esperbally true when it ocrurs even-aged with Dourlas fir and has heen thrifty enough to keep up with it and form a part of the main stand. On the whole the quality is poor.

The fir type occurs in the southwestern part of the sale, on the higher elevations. The chief species in this type are amabilis fir and noble fir, both of them attaining commercial size. The noble fir is the better of the two, growing tall, straight, and clean, and usually of good quality. The amabilis fir is more limby, even when it attains its best development.

The mountain hemlock is almost of negligible area within the sale. The timber is of no commercial value and of very poor quality.

Western red cedar type has an extent of a few acres. The timber is of medium quality.

The types outside and east of the sale boundary are very similar in character to those within, hut differ considerably in extent of their area. Here the mountain hemlock and western hemlock types attain their greatest development. The younger age classes of Douglas fir and the true fir type are also represented. The species in these types are generally poorly leveloped, limhy, and altogether a very poor quality, with no commercial value.

The area south of the sale boundary is within the Bull Run division of the Oregon National Forest. Since this area has been set apart to protect the water supply of the city of Portland, it can not be logged. The timber soon runs into undesirable species, which are neither commercial in size nor quality.

For 3 miles on the west the sale boundary and the boundary of the Bull Run division are the same. The timber in this portion of the Bull Run division and along the west boundary of the sale is of good quality. It is composed very largely of amabilis fir, noble fir, and second-growth Douglas fir.

From the southeast corner of section 15 the boundary runs in a general northeast direction until it reaches the base line. Along this boundary one finds either the ends of long fingers of timber extending up the mountain side from the stand lower down, or a deforested (burned) area which is restocking with Douglas fir, but nothing of commercial value.

Topography.-The proposed sale area is in a mountainous region. In one place the west boundary is one-halt mile east of the summit of the Cascade Range. Mount Hood, an extinct rolcano reaching an eleration of $11,2.25$ feet, is 5 miles southeast of the south boundary. This region has been the scene of a great deal of volcanic activity, as evidenced by the tilted and twisted condition of the rock formation. The country has been covered by lava flows from Mount Hood which have been planed down by glacial action, magments of these glaciers still clinging to the slopes of the mountain. Ladd Creek, one of the streams on the area, has its source in a glacier of the same name 3 miles southeast of the south boundary.

The topography within the boundary of the sale area can be classed as steep and rough. Along the main streams in the lower portions of the watershed south of the forest boundary there is a considerable amount of bottom and bench land, the greater portion of which is patented. The portion of the watershed within the sale boundaries 
is practically all on the slopes, which are steep and broken. Numerous rock slides, cliffs, and rock outcrops occur in some places, the slides covering 20 to 50 acres. The streams on the sale area are as a rule small and with a heavy fall, the slopes rising didirectly from the stream beds and as a rule are steep, in some places occurring as canyons. These rocky areas and streams make railroad construction and logging operations difficult. The West Fork of Ifood River and main tributaries do not afiect the sale area to any extent, as their course is for the greater yart through patented lands. The beds of the streams are rocky; there are no falls, but rapids are numerous. The gradient along tributary streams is too great to permit the construction of railroads ip their valleys. A detailed description of the topographic features of the area is unnecessary, as the accompanying map shows it better than a description could give it.

Arcessibility.-The Orezon Lumber Co. operates a sawmill, with a capacity of $30,000,000$ feet b. m. frer anmum, at Dee, a saidon on the Nount Ifood Railway. which is owned by the same interests that own the mill. Dee is 12 miles distant from Hood River, a station 64 miles east of Portland, Oreg., on the O.- WW . R. \& N. Co. transcontinental line. The log supply for the mill during the past season bas been obtained from the logring (amp operated by the company in the West Fork of IIood River Valley, $5 \frac{1}{2}$ miles southwest of the mill. The north boundary of the proposed area is approximately 3 miles southwest of the lorging (amp); therefore the sale area is $8 \frac{1}{2}$ miles from the sawmill where the timber under consideration will be manufactured.

The discussion of freight rates is a complicated matter, as there are so many variables The freight rate on lumber from Hood River, Oreg., to Chicago is 53 cents per 100 pounds; the coast rate is 55 cents; the Dee rate is the same as the coast. The coast rate to Denver is 40 cents, the Dee rate 36 cents, the Hood River rate 34 cents. To the Salt Lake market the Dee rate is $1 \frac{1}{2}$ cents less than the coast rate. The coast rate to Omaha is 50 cents, the Dee rate is the same, the Hood River rate is 48 cents. This then puts Dee on the same basis as the coast mills to the markets outside of Denver and Salt Lake market, while Hood River has the advantage over the coast. rate of from 2 to 6 cents per 100 pounds. The local rate from Dee to Hood River is 5 cents per 100 pounds; on through shipments the rate is 2 cents, which makes up the 2 cents difference between the Hood River and Dee rates.

It is evident that any gain due to a lower freight rate is dependent upon the distribution of the output. If all of the cut goes to Omaha and chicago rate points there would be no difference between Dee and the coast mills. If all of the cut goes to Denver rate points the gain on shipments from Dee over the coast would be 4 cents per 100 pounds, or approximately $\$ 1$ per thousand feet. If shipped to both markets the gain will be in proportion to the grade of lumber shipped to each market. On clears shipped to the Denver market the gain would be about 80 cents per thousand feet, and on rough common $\$ 1.30$ per thousand feet. The gain is therefore not only dependent upon the distribution of the output, but upon the distribution of the grades of lumber produced. Due to the number of factors to be considered the determination of the gain from advantageous freight rates is a difficult matter. The cut of the mill has been distributed by grades nver the market that the mill can reach without a differential against them and the gain computed on that basis. This gain amounts to 20 cents per thousand feet, which has been distributed over the lumber values by grades.

The appraisal is based upon the timber being manufactured at the sawmill at Dee, Oreg., the use of the present railroad up the West Fork of IIood Rirer, the construction of a railroad to and through the sale area.

\section{INVESTMENT.}

Railroads.-The railroad from the sawmill at Dee to the present terminus is of standard construction throughout with light currature and gradient. This road will tap approximately one billion feet of private and national forest timber on the ITest Fork of Hood River. Lake Fork and Divers (reek. Depreciation is hased upon this amount of timber. The investment is the present value of the road and a residual instead of a wrecking value is allowed at the end of 12 years.

From the terminus of the present line the railroad to the sale area as surveyed is on the south side of the valley, well above the rirer to avoid rock cliffs and canyons, entering the forest at an elevation of $2,0.50$ feet. This portion of the road will not pass through timber. A great deal of rock will be encountered in the construction of this portion of the railroad. Several canyons are crossed, necessitating long and high trestles. The construction as a whole is heary, with a correspondingly heary cost. From the forest boundary the road will continue up the valley into sec. 26 , with spurs into secs. 13 and 23 , T. 1 S., R. 8 E. 
To tap the timber on the higher elevations switchlarks or an incline must be used. The appraisal plan for reaching the timber on the higher elevations is to construct an incline from the main line to the high lines on the slopes. The high lines to be constructed through secs. 1, 12, 13, and 14, T. 1 S., R. 8 E. E., secs. 6 and 7, T. 1 S., R. 9 E., and through secs. $24,25,26,35$, and 36, T. I S., R. 8 E., Willamette meridian, and loading spurs to be constructed at landings. With this development the greater part of the timber can be yarded direct to the cars. The unit cost of construction south of the forest boundary is less than outside. On the patented land inside the forest construction will be lighter than on forest land, the railroad being on the valley floor or on gentle slopes. The new construction necessary to $\log$ both private and national iorest timber will be $2: 3$ miles. exclusive of temporary spurs, of which there are 6 miles.

The railroad from the terminus of the present railroad to and inside the national linest will tap approximately $480,000,000$ feet of timber; depreciation is hased upon this amount. The roadbed, ties, and bridges have no value at the end of the sale; steel and fastenings have a wrecking value for removal and use elsewhere.

Railroad equipment. - The equipment for the transportation of logs from woods to mill to consist of 1 direct connected locomotive for main line haul, 2 general locomotives for spur haul, and 60 connected logging trucks equipped with air. With the exception of one locomotive the present railroad equipment of the Oregon Lumber ('o. is too small in size and capacity for the eronomical transportation of logs from the sale area and the appraisal contemplates the purchase of new equipment.

Longing. - The timber in the valley bottom is on patented. land; the national forest timber within the sale area is as a rule on the slopes or at the heads of streanis. Logging the privately owned timber can be done at a low cost, as it stands on good ground. Logrging national forest timber will be a different proposition: the timber standing on the slopes, which in places are broken by cliffs and rock slides, will have a higher breakage than that in the valley. yarding distance will be greater. roarling will be neceessary to reach timber where railroad construction cost is prohibitive. Railroad construction will be heavier, as the roads will be on the slopes above the valley floor. All these factors make for higher logging costs.

p. The method of logging by which the timber can be removed cconomically is by the combination of overhead and ground yarding, the equipment to consist of 3 overhead yarders, 1 yarder, 1 roader, 3 loading engines, and 1 incline engine. The output per annum is placed at $40,000,000$ feet in an operating season of nine months.

The stand of timber. national forest and private. is $480,000,000$ feet, and the output 40, 000,000 feet jer annum: therefore it will require 12 years to log the timber embraced in the appraisal.

The following is a tabulation of investments:

\section{Existing main line railroad (5 miles).}

\begin{tabular}{|c|c|c|c|c|}
\hline Item. & $\begin{array}{l}\text { Present } \\
\text { worth. }\end{array}$ & $\begin{array}{c}\text { Deprecia- } \\
\text { tion, } 12 \\
\text { years. }\end{array}$ & $\begin{array}{l}\text { Residual } \\
\text { value. }\end{array}$ & $\begin{array}{c}\text { Average } \\
\text { investment. }\end{array}$ \\
\hline $\begin{array}{l}\text { Construction under rails.... } \\
\text { Steel and fastenings....... }\end{array}$ & $\begin{array}{r}\$ 22,000 \\
20,000\end{array}$ & $\begin{array}{r}\$ 10,650 \\
10,800\end{array}$ & $\begin{array}{r}\$ 11,350 \\
9,200\end{array}$ & \\
\hline Total... & 42,000 & 21,450 & 20,550 & $\$ 32,168$ \\
\hline
\end{tabular}

Logging plant railroad, under rails (23 miles).

\begin{tabular}{|c|c|c|c|c|c|c|c|c|c|}
\hline Years. & $\begin{array}{l}\text { Invest- } \\
\text { ment at } \\
\text { begin- } \\
\text { ning of } \\
\text { year. }\end{array}$ & $\begin{array}{l}\text { Depre- } \\
\text { ciation } \\
\text { during } \\
\text { year. }\end{array}$ & $\begin{array}{l}\text { Addi- } \\
\text { tional } \\
\text { invest- } \\
\text { ment at } \\
\text { end of } \\
\text { year. }\end{array}$ & $\begin{array}{l}\text { Average } \\
\text { invest- } \\
\text { ment. }\end{array}$ & Years. & $\begin{array}{l}\text { Invest- } \\
\text { ment at } \\
\text { begin- } \\
\text { ning of } \\
\text { year. }\end{array}$ & $\begin{array}{l}\text { Depre- } \\
\text { ciation } \\
\text { during } \\
\text { year. }\end{array}$ & $\begin{array}{l}\text { Addi- } \\
\text { tional } \\
\text { invest- } \\
\text { ment at } \\
\text { end of } \\
\text { year. }\end{array}$ & $\begin{array}{l}\text { Average } \\
\text { invest- } \\
\text { ment. }\end{array}$ \\
\hline $\begin{array}{l}1 \ldots \ldots \ldots \\
2 \ldots \ldots \ldots \\
3 \ldots \ldots \ldots \\
4 \ldots \ldots \ldots \\
6 \ldots \ldots \ldots\end{array}$ & $\begin{array}{r}\$ 53,850 \\
57,863 \\
59,347 \\
53,831 \\
50,815 \\
43,374\end{array}$ & $\begin{array}{r}\$ 4,487 \\
7,141 \\
10,016 \\
9,216 \\
9,991 \\
8,391\end{array}$ & $\begin{array}{r}\$ 8,500 \\
8,625 \\
4,500 \\
6,200 \\
2,550 \\
5,825\end{array}$ & 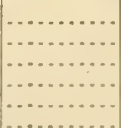 & $\begin{array}{l}8 \ldots \ldots \\
9 \ldots \ldots \\
10 \ldots \ldots \\
11 \ldots \ldots \\
12 \ldots \ldots\end{array}$ & $\begin{array}{r}\$ 47,366 \\
43,345 \\
36,042 \\
30,233 \\
15,124\end{array}$ & $\begin{array}{l}\$ 9,471 \\
10,833 \\
12,009 \\
15,109 \\
15,124\end{array}$ & $\begin{array}{r}\$ 5,450 \\
3,530 \\
6,200 \\
\ldots \ldots . . .\end{array}$ & \begin{tabular}{|l|}
$\ldots \ldots$ \\
$\ldots \ldots$ \\
$\ldots \ldots$ \\
$\ldots \ldots$ \\
$\ldots \ldots$
\end{tabular} \\
\hline & $40,80 \mathrm{~S}$ & 7,862 & 14,420 & & Total.. & 531,993 & 119,650 & 65,800 & $\$ 44,333$ \\
\hline
\end{tabular}


Logging plant-Rails and fastenings.

\begin{tabular}{|c|c|c|c|c|c|}
\hline Years. & $\begin{array}{l}\text { Invest- } \\
\text { ment, be- } \\
\text { ginning } \\
\text { of year. }\end{array}$ & $\begin{array}{l}\text { Deprecia- } \\
\text { tion dur- } \\
\text { ing year. }\end{array}$ & $\begin{array}{c}\text { Additional } \\
\text { invest- } \\
\text { ment at } \\
\text { end of year. }\end{array}$ & $\begin{array}{l}\text { Wrecking } \\
\text { ralue. }\end{array}$ & $\begin{array}{c}\text { Average } \\
\text { investment. }\end{array}$ \\
\hline 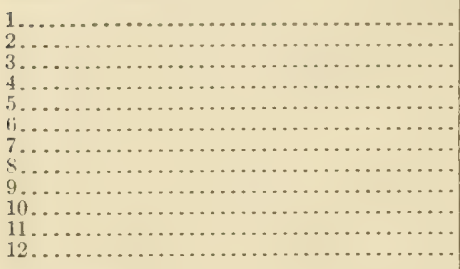 & $\begin{array}{r}\$ 33,350 \\
41,050 \\
48,336 \\
52,208 \\
49,601 \\
46,994 \\
48,517 \\
53,985 \\
57,005 \\
53,546 \\
50,087 \\
46,628\end{array}$ & $\begin{array}{r}\$ 1,500 \\
1,914 \\
2,328 \\
2,607 \\
2,607 \\
2,607 \\
2,792 \\
3,180 \\
3,459 \\
3,459 \\
3,459 \\
3,459\end{array}$ & 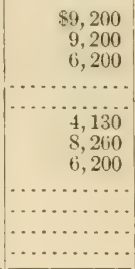 & 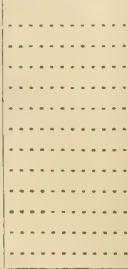 & 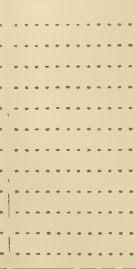 \\
\hline Total.......... & 581,307 & 33,371 & 43,190 & $\$ 43,169$ & $\$ 48,442$ \\
\hline
\end{tabular}

Locomolives and truicks.

\begin{tabular}{c|r|r|r|r}
\hline Years in use. & $\begin{array}{r}\text { Initial } \\
\text { investment. }\end{array}$ & $\begin{array}{c}\text { Deprecia- } \\
\text { tion, 12 } \\
\text { years. }\end{array}$ & $\begin{array}{c}\text { Wrecking } \\
\text { value. }\end{array}$ \\
\hline $12 \ldots \ldots \ldots \ldots \ldots \ldots \ldots \ldots \ldots \ldots \ldots \ldots \ldots \ldots \ldots \ldots \ldots \ldots$ & $\$ 81,250$ & $\$ 65,344$ & $\$ 15,900$ & $\$ \begin{array}{c}\text { Average } \\
\text { investment. }\end{array}$ \\
\hline
\end{tabular}

Investment includes present worth of one locomotive in use by mill company.

Donkey engines.

\begin{tabular}{|c|c|c|c|c|c|}
\hline Years. & $\begin{array}{l}\text { Invest- } \\
\text { ment, be- } \\
\text { ginning } \\
\text { of year. }\end{array}$ & $\begin{array}{l}\text { Deprecia- } \\
\text { tion each } \\
\text { year. }\end{array}$ & $\begin{array}{l}\text { Additional } \\
\text { invest- } \\
\text { ment at } \\
\text { end of year. }\end{array}$ & $\begin{array}{l}\text { Wrecking } \\
\text { value. }\end{array}$ & $\begin{array}{c}\text { Average } \\
\text { investment. }\end{array}$ \\
\hline 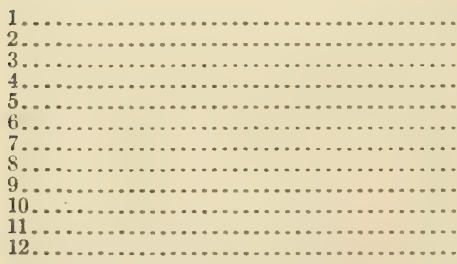 & $\begin{array}{r}\$ 47,000 \\
42,910 \\
38,820 \\
34,730 \\
30,640 \\
26,550 \\
22,460 \\
18,370 \\
14,250 \\
10,190 \\
42,100 \\
38,010\end{array}$ & $\begin{array}{r}\$ 4,090 \\
4,090 \\
4,090 \\
4,090 \\
4,090 \\
4,090 \\
4,090 \\
4,090 \\
4,090 \\
4,090 \\
4,090 \\
4,090\end{array}$ & 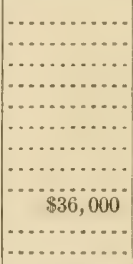 & n..... & 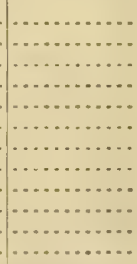 \\
\hline Tota & 366,060 & 49,080 & 36,000 & $\$ 33,920$ & $\$ 30,505$ \\
\hline
\end{tabular}

\section{Camps.}

\begin{tabular}{c|c|r|r|r}
\hline Years in use. & $\begin{array}{c}\text { Initial } \\
\text { invest- } \\
\text { ment. }\end{array}$ & $\begin{array}{c}\text { Deprecia- } \\
\text { tion, 12 } \\
\text { years. }\end{array}$ & $\begin{array}{c}\text { Wrecking } \\
\text { value. }\end{array}$ & $\begin{array}{c}\text { Average } \\
\text { invest- } \\
\text { ment. }\end{array}$ \\
\hline $12 \ldots \ldots \ldots \ldots \ldots \ldots \ldots \ldots \ldots \ldots \ldots \ldots \ldots \ldots \ldots \ldots \ldots$ & $\$ 7,800$ & $\$ 7,200$ & $\$ 600$ & $\$ 1,500$ \\
\hline
\end{tabular}


Blocks and tools.

\begin{tabular}{|c|c|c|c|c|c|}
\hline Tears. & $\begin{array}{l}\text { Invest- } \\
\text { ment at } \\
\text { begimning } \\
\text { of year. }\end{array}$ & $\begin{array}{l}\text { Deprecia- } \\
\text { tion during } \\
\text { year. }\end{array}$ & $\begin{array}{l}\text { Additional } \\
\text { invest- } \\
\text { ment, end } \\
\text { of year. }\end{array}$ & $\begin{array}{l}\text { Wrecking } \\
\text { value. }\end{array}$ & $\begin{array}{l}\text { Average } \\
\text { invest- } \\
\text { ment. }\end{array}$ \\
\hline \multirow[t]{2}{*}{ 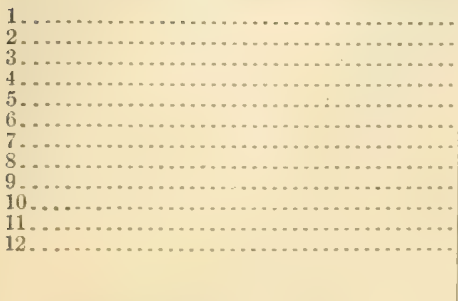 } & $\begin{array}{r}\$ 6,120 \\
4,720 \\
3,320 \\
4,920 \\
3,520 \\
3,420 \\
5,020 \\
3,620 \\
2,220 \\
3,820 \\
2,420 \\
2,320\end{array}$ & $\begin{array}{r}\$ 1,400 \\
1,400 \\
1,400 \\
1,400 \\
1,400 \\
1,400 \\
1,400 \\
1,400 \\
1,400 \\
1,400 \\
1,400 \\
1,400\end{array}$ & $\begin{array}{r}\$ 3,000 \\
1,300 \\
3,000 \\
\ldots \ldots \\
3,000 \\
1,300 \\
\ldots \ldots \ldots\end{array}$ & 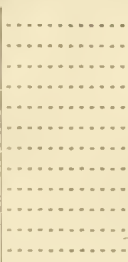 & 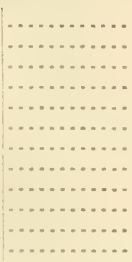 \\
\hline & 54,440 & 16,500 & 11,600 & $\$ 920$ & $\$ 1,533$ \\
\hline
\end{tabular}

Summary-Logging-plant investment.

Main line railiroad.

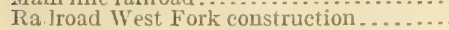

Vest Fork, rails and fastenings.

Locomotives and trueks.

Donkey engines.

Camps....

Blocks and tools.

Total.

\begin{tabular}{|c|c|c|c|c|c|}
\hline $\begin{array}{l}\text { Initial } \\
\text { invest- } \\
\text { ment. }\end{array}$ & $\left|\begin{array}{c}\text { Yearly } \\
\text { deprecia- } \\
\text { tion. }\end{array}\right|$ & $\begin{array}{c}\text { Total } \\
\text { deprecia- } \\
\text { tion. }\end{array}$ & $\mid \begin{array}{c}\text { Addi- } \\
\text { tional in- } \\
\text { vestment. }\end{array}$ & $\begin{array}{l}\text { Wreck- } \\
\text { ing } \\
\text { value. }\end{array}$ & $\begin{array}{l}\text { Average } \\
\text { invest- } \\
\text { ment. }\end{array}$ \\
\hline $\begin{array}{r}\$ 42,000 \\
53,850 \\
33,350 \\
81,250 \\
47,000 \\
7,800 \\
6,120\end{array}$ & $\begin{array}{r}\$ 1,787 \\
9,971 \\
2,781 \\
5,445 \\
4,090 \\
600 \\
1,400\end{array}$ & $\begin{array}{r}\$ 21,450 \\
119,650 \\
33,371 \\
65,344 \\
49,080 \\
7,200 \\
16,800\end{array}$ & $\begin{array}{r}\$ 65,800 \\
43,190 \\
\ldots \ldots \ldots \\
36,000 \\
\ldots \ldots \ldots\end{array}$ & $\begin{array}{r}\$ 20,550 \\
43,169 \\
15,906 \\
33,920 \\
600 \\
920\end{array}$ & $\begin{array}{r}\$ 32,168 \\
44,333 \\
48,442 \\
56,259 \\
30,505 \\
4,500 \\
4,533\end{array}$ \\
\hline 271,370 & 26,074 & 312,895 & 156,590 & 115,065 & $22 C, 740$ \\
\hline
\end{tabular}

\section{Logging cost.}

\begin{tabular}{|c|c|c|c|c|c|c|c|}
\hline Items. & C. & If. & G. & T. & R. & D. & T. \\
\hline \multicolumn{8}{|l|}{ Woods: } \\
\hline Falling and hucking.. & $80.63 \pi$ & & & & & & $\$ 0.63 \mathrm{~s}$ \\
\hline Yarding and roading . . . . . . . . . . . & 1.050 & & & & & & 1.050 \\
\hline $\operatorname{din} \ldots \ldots \ldots \ldots \ldots$. & .290 & & & & & & .290 \\
\hline $\begin{array}{l}\text { Landings.................. } \\
\text { Railroad: }\end{array}$ & .013 & & & & & & .063 \\
\hline \multicolumn{8}{|l|}{ Railroad: } \\
\hline 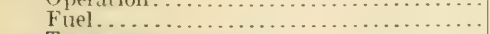 & .150 & & & . & & & $\begin{array}{l}.300 \\
.150\end{array}$ \\
\hline 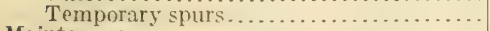 & .041 & & & $\cdots$ & . & - & .041 \\
\hline \multicolumn{8}{|l|}{ Maintenance: } \\
\hline 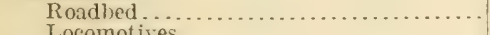 & & s0. 160 & & & & & .160 \\
\hline 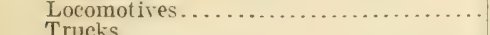 & $\cdots \cdots$ & .010 & & & & ‥ & . \\
\hline 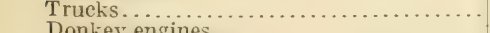 & - & $.0 \times 5$. & & & & & .0 \\
\hline 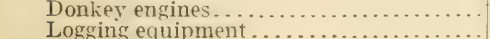 & - & .067 & & & & & $.06 \mathrm{j}$ \\
\hline $\begin{array}{l}\text { Logging equipment . . . . . . . . . . . . . . . } \\
\text { Supplies: }\end{array}$ & \multirow{2}{*}{\multicolumn{4}{|c|}{ Supplies: }} & & - & .09 \\
\hline 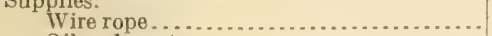 & & .240 & & & & & \\
\hline Oil and waste.... & ...... & .020 & & & & & .020 \\
\hline General........... & ....... & .035 & & & & . & .035 \\
\hline \multicolumn{8}{|l|}{ Insurance and taxes: } \\
\hline Liability insurance.. & & & & $\$ 0.060$ & & & .060 \\
\hline F. $\mathrm{S}$ Taxes regulations: & & & & .080 & & & .080 \\
\hline Snags, fire lines and slash burning... & & & & & 80.108 & & .108 \\
\hline \multicolumn{8}{|l|}{$\begin{array}{l}\text { General expense: } \\
\text { Supervision }\end{array}$} \\
\hline Supervision ...... & ... & $\ldots$ & $\$ 0.200$ & $\cdots$ & $\ldots$ & .. & .26 \\
\hline \multicolumn{8}{|l|}{ Depreciation: } \\
\hline Locomotives and trucks. & & & & & & \$0. 136 & .136 \\
\hline Donkey engit & & & & & & .102 & .102 \\
\hline Steel and fastenin & & $\ldots$ & & . & $\ldots$ & .069 & .069 \\
\hline $\mathrm{Can}$ & $\ldots$ & $\ldots$ & $\ldots$ & ... & $\ldots$ & .015 & .015 \\
\hline Tools and blocks.... & ... & .... & . & ... & $\ldots$ & .035 & .035 \\
\hline Railroad construetion ... & $\ldots$ & . & 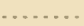 & .... & $\ldots \ldots$ & .249 & .249 \\
\hline 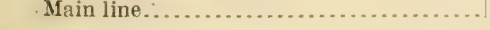 & & & & & & .045 & .045 \\
\hline Total. & 2.532 & .737 & .310 & .140 & .108 & .651 & 4.478 \\
\hline
\end{tabular}


Milling.-The old mill at Dee, Oreg., was destroyed by fire about lour years ago. The present mill is built on the site of the old one and has been in operation two years. It is a modern, electrically driven, individual motor band mill, with an annual capacity of $30,000,000$ feet, which is to be increased to $40,000,000$ feet. The power is generated in a hydroelectric plant at the mill. The available flow of Hood River is given at 220 second-feet. The power plant requires 312 second-feet. Owing to this lack of water, the mill is shut down on an average of two hours each day waiting for the storage basin to fill. The irrigation associations of the Hood River Valley obtaining water from the East Fork of Ifood River filed suit to restrain the Oregon Lumber ('o. from using the water, claiming it was needed for irrigation. The court held that irrigation is the highest use for the water, and that the company could install a steam plant and utilize the mill waste to generate power, while the irrigationists had no alternative. The company is installing a steam-electric plant and increasing the mill capacity to $40,000,000$ feet per annum by installing additional machinery.

Investment in milling plant is the depreciated value of the present plant plus the new equipment to be added.

Milling plant investment.

$\ldots \ldots \ldots \ldots$

The present worth of the milling plant is the value at the beginning of the operation on the sale area. The total life of the mill is 15 years, 3 of which are prior to and 12 during the life of the sale. The plant has a wrecking instead of a residual value.

Total investment, logging and milling plant.

\begin{tabular}{|c|c|c|c|c|c|c|}
\hline Item. & $\begin{array}{l}\text { Initial } \\
\text { invest- } \\
\text { ment. }\end{array}$ & $\begin{array}{c}\text { Yearly } \\
\text { deprecia- } \\
\text { tion. }\end{array}$ & $\begin{array}{c}\text { Total } \\
\text { deprecia- } \\
\text { tion. }\end{array}$ & $\begin{array}{l}\text { Addi- } \\
\text { tional } \\
\text { invest- } \\
\text { ment. }\end{array}$ & $\begin{array}{c}\text { Residual } \\
\text { and } \\
\text { wrecking } \\
\text { value. }\end{array}$ & $\begin{array}{l}\text { A verage } \\
\text { invest- } \\
\text { ment. }\end{array}$ \\
\hline $\begin{array}{l}\text { Logging plant........... } \\
\text { Milling plant........... } \\
\text { Logs in pond and woods } \\
\text { Lumber in yard......... }\end{array}$ & $\begin{array}{r}\$ 271,370 \\
214,810 \\
15,000 \\
88,000\end{array}$ & $\begin{array}{r}\$ 26,074 \\
15,825 \\
\ldots \ldots\end{array}$ & $\begin{array}{r}\$ 312,895 \\
189,900 \\
\ldots \ldots\end{array}$ & $\begin{array}{l}\$ 156,590 \\
\ldots \ldots \ldots \\
\ldots \ldots \ldots\end{array}$ & $\begin{array}{r}\$ 115,065 \\
24,910 \\
15,000 \\
89,000\end{array}$ & $\begin{array}{r}\$ 220,740 \\
127,772 \\
15,000\end{array}$ \\
\hline Total. & 589,180 & 41,899 & 502,795 & 156,590 & 242,975 & 451,512 \\
\hline
\end{tabular}

Working capital.

Accounts receivable.

Advance stumpage...

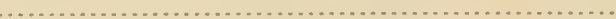

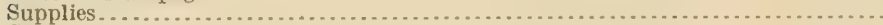

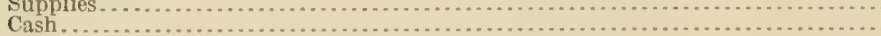

Total.

\begin{tabular}{r|r}
$\begin{array}{r}\text { Initial } \\
\text { invest- } \\
\text { meat. }\end{array}$ & $\begin{array}{c}\text { Average } \\
\text { invest- } \\
\text { ment. }\end{array}$ \\
\hline$\$ 62,000$ & $\begin{array}{r}\$ 62,000 \\
5,500\end{array}$ \\
6,500 & 6,500 \\
10,000 & 10,000 \\
\hline 84,000 & 84,000 \\
\hline
\end{tabular}


Milling costs.

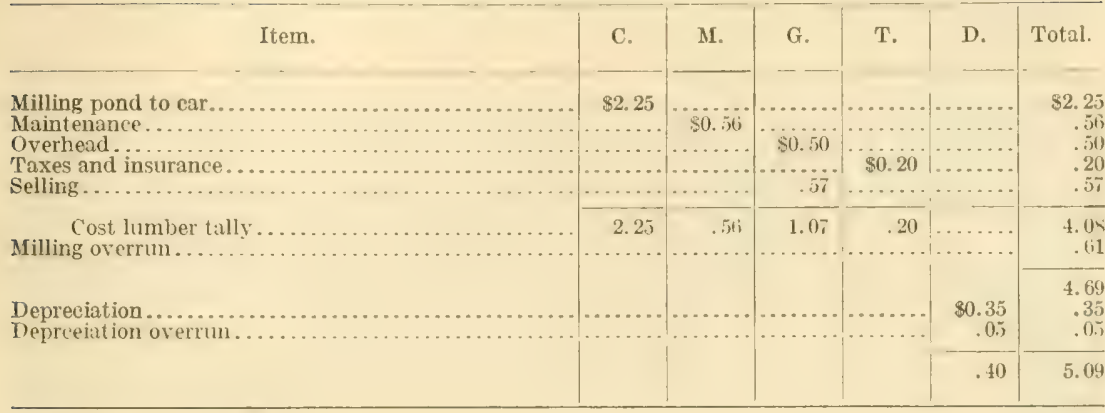

Milling cost less depreciation . . . . . .

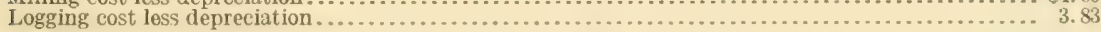

$8 . \overline{82}$

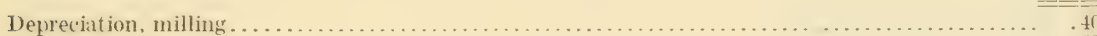

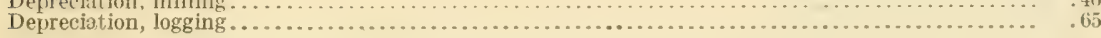

Douglas fir and noble fir.- The Douglas fir is admirably suited for the manufacture of No. 1 common lumber of all sizes and patterus, with a fair percentage of select common. The quality inspection shows an average of $10 \frac{1}{2}$ per cent of No. "2 clear and better lumber. This amount can be produced with reasonable care in manufacture. It is true, however, that in texture, mellowness, and color these upper grades will not be equal to those from timber in the coast region.

The small percentage of noble fir is included with the Douglas fir. The quality averages good, the best of any species on the area; here and there occur many single specimens representing the typical growth in volume and quality. It appears that in places noble fir has been tallied and computed as amabilis fir.

Grades of lumber based on No. 1 logs, 3 per cent; No. $2 \log s, 28$ per cent; No. 3 $\operatorname{logs}, 69$ per cent.

No $1 \mathrm{~V}$. G. flooring, 1 by 4 inches, 1.2 per cent, at $\$ 25.10$. $\$ 0.30$

No. 2 V. G. flooring, 1 by 4 inches, 2.8 per cent, at $\$ 22.10 \ldots \ldots \ldots \ldots \ldots \ldots \ldots . . . . .62$

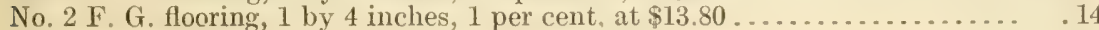

No. 2 clear and better finish, 2.5 per cent, at $\$ 25.20 \ldots \ldots \ldots \ldots \ldots \ldots \ldots \ldots \ldots . . . .63$

No. 2 clear and better siding and rustic, 3 per cent, at $\$ 16.10 \ldots \ldots . \ldots . \ldots .48$

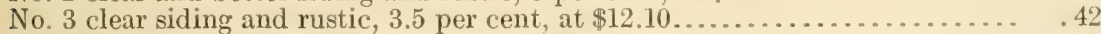

Car sills, No. 1 common, 5 per cent, at $\$ 14.50 \ldots \ldots \ldots \ldots \ldots \ldots \ldots \ldots \ldots \ldots \ldots \ldots . . \ldots \ldots . . . \ldots \ldots$

Select common, 4 per cent, at $\$ 13 \ldots \ldots \ldots \ldots \ldots \ldots \ldots \ldots \ldots \ldots \ldots \ldots \ldots \ldots \ldots . . \ldots \ldots . . . \ldots \ldots$

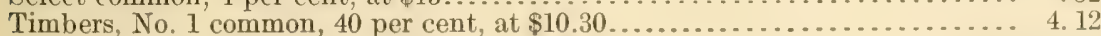

No. 1 common dimensions, 15 per cent, at $\$ 9.40 \ldots \ldots \ldots \ldots \ldots \ldots \ldots \ldots \ldots \ldots \ldots . . \ldots \ldots 1$

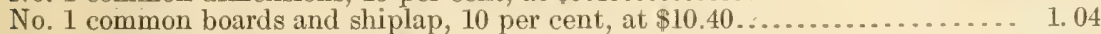

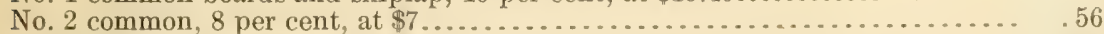

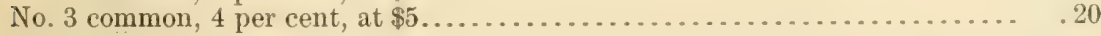

Average value..................................... $\$ 11.17$

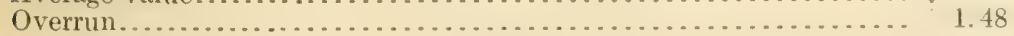

12.65

Discounts....................................... 17

12.48

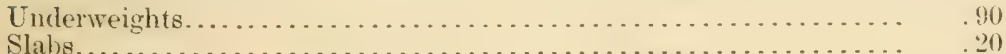

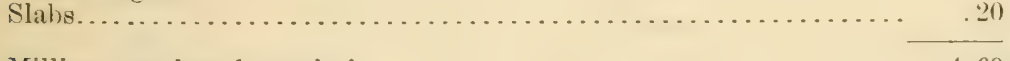

Milling cost, less depreciation.......................... 4.69

Logging cost, less depreciation........................ 3.83 


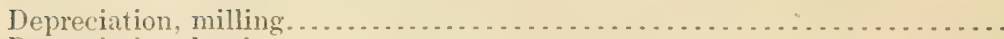

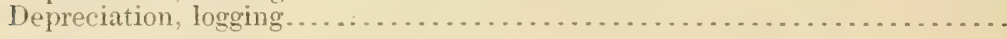

The Mount Hood Railway and the Oregon Lumber Co. use slabs from the mill for fuel in their locomotives. Surplus slabs are sold at the town of Hood River and in the valley; this surplus is not large, as the locomotives require most of the slabs produced. The price received for slabs could not be learned, therefore their value is computed on a fuel-value basis, which has been placed at $\$ 0.20$ per thousand feet.

The overrun value in this appraisal is 13.2 per cent of the average value of the product; the overrun in volume, 15 per cent. The product being cut into heavy material and the taper of logs quite large it is believed that this overrun is justified. The gain from werrun in Douglas fir is $\$ 1.48$, from slabs $\$ 0.20$, from underweights 80.90 per thousturl feet, a net gain of 82.58 per thousand feet, which added to the arerage value of $\$ 11.17$ makes an averige value of $\$ 13.75$ from which $\$ 0.17$ per thousand feet must be deducted for discounts, leaving an average value of $\$ 13.58$ per thousand feet log scale.

Discounts.-Discounts are based upon two-thirds of the value of the cut, being discounterl at 2 per cent. This makes a discount of 1.33 per cent on the total cut, which is the basis of the discount of $\$ 0.17$ derlucted from the average value plus overrun of $\$ 12.65$ per thousand feet.

If setth white pinc.- This species comprises 1.1 per cent of the total stand, it is of fair size and quality, and is estimated to cut 20 per cent No. 2 shop and better.

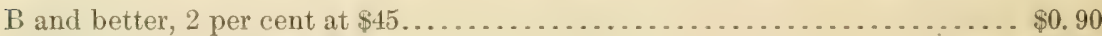

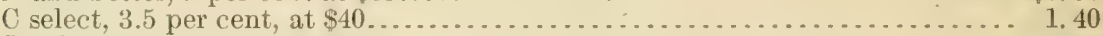

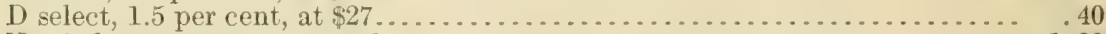

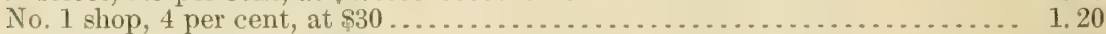

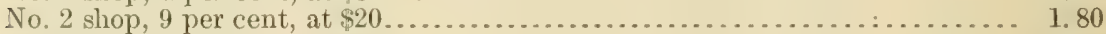

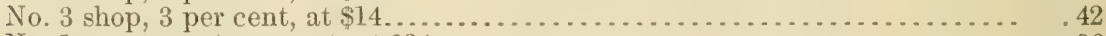

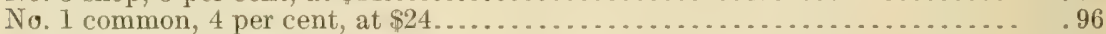

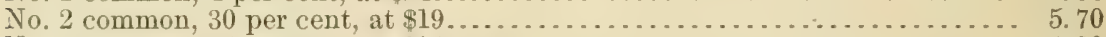

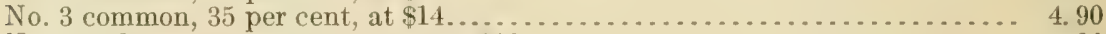

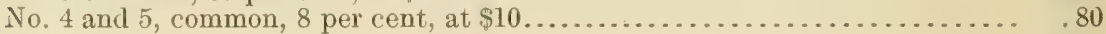

18. 48

The cost of operation is higher than in the other species, due to the fact that this species does not occur in any body, but scattered singly throughout the area, making it necessary to rehandle the product in small quantities, which is an expensive operation.

Average value...................................... $\$ 18.48$

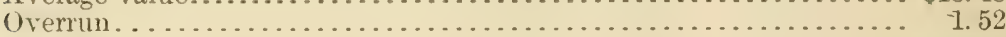

20. 00

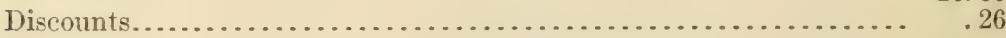

19. 74

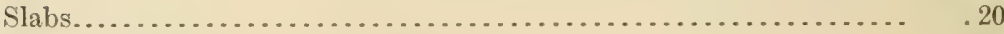

Cost of production, less depreciation........................ 10.00

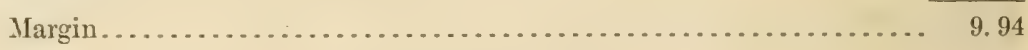

Hemlock and amabilis fir.

\begin{tabular}{|c|c|c|c|}
\hline Grade. & $\begin{array}{l}\text { Per cent } \\
\text { of each. }\end{array}$ & $\begin{array}{l}\text { Value } \\
\text { per thou- } \\
\text { sand. }\end{array}$ & $\begin{array}{l}\text { Propor- } \\
\text { tional } \\
\text { value. }\end{array}$ \\
\hline 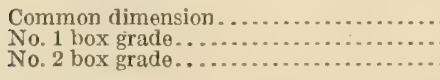 & $\begin{array}{l}40 \\
35 \\
25 \\
\end{array}$ & $\begin{array}{r}\$ 9.40 \\
10.40 \\
6.00\end{array}$ & $\begin{array}{r}\$ 3.76 \\
3.64 \\
1.50\end{array}$ \\
\hline Average value.. & $\ldots$ & & 8.90 \\
\hline
\end{tabular}


Average value

Overrun

I)iscounts.

Underweight

1. 10

Slabs.

4. 69

Milling, less depreciation

Logging, less depreciation

3.83

Depreciation, milling.

Depreciation, logging

Overrun value is $\$ 1.17$, underweights $\$ 1.10$, slabs $\$ 0.20$ per thousand feet, a net gain from these sources of $\$ 2.47$ per thousand feet, which added to the average value of lumber of $\$ 8.90$, makes a total value of $\$ 11.37$, from which $\$ 0.13$ must be deducted, making a net value of $\$ 11.24$ per thousand feet $\log$ scale.

\section{Western red cedar.}

3 per cent No. 2 clear and better finish, at $\$ 35$

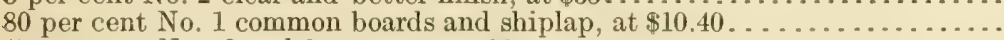

Average value ................................... \$10. 39

Overrun.

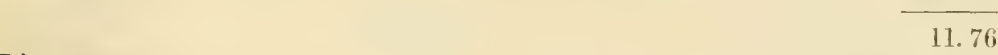

Discounts.

Underweights

Slabs.

Milling cost less depreciation.

Logging cost less depreciation

\section{Margin}

Investment and profit margin.-Total average investment in logging and milling plant, logs and lumber in stock, is $\$ 451,512$, on which a margin of 20 per cent is allowed, or $\$ 90,302$ per annum, which prorated over a cut of $40,000,000$ feet per annum is $\$ 2.26$ per thousand feet.

Average investment in accounts receivable, stumpage, supplies, and.cash is $\$ 84,000$, on which 8 per cent profit margin is allowed, or $\$ 6,720$, which prorated over a cut of $40,000,000$ feet per annum is $\$ 0.17$ per thousand feet. The combined profit margin is $\$ 2.26$ plus $\$ 0.17$, or $\$ 2.43$ per thousand feet $\log$ scale. Depreciation is $\$ 0.65$ on logging plant and $\$ 0.40 \mathrm{on}$ milling plant, a combined depreciation of $\$ 1.05$ per thousand feet $\log$ scale. Profit margin and depreciation is $\$ 3.48$ per thousand feet. 
(1) Douglas fir and noble fir.

(2) White pine.

(3) Western red cedar.

\begin{tabular}{|r|r|r}
$\begin{array}{c}\text { Selling } \\
\text { price. }\end{array}$ & $\begin{array}{c}\text { Operat- } \\
\text { ing cost. }\end{array}$ & Margin. \\
& & M8.52 \\
$\$ 13.58$ & $\$ 5.06$ \\
19.94 & 10.00 & 9.94 \\
13.05 & 8.52 & 4.53 \\
11.24 & 8.52 & 2.72 \\
& &
\end{tabular}

(1) 73.3 per cent by $\$ 5.06=\$ 3.71$

(2) 1.1 per cent by $9.94=.11$

(3) 2.5 per cent by $4.53=.11$

(4) 23.1 per cent by $2.72=.63$

4.56

Depreciation $\$ 1.05$ plus profit $\$ 2.43=\$ 3.48 \div 4.56=\$ 0.7631$.

(1) $\$ 5.06$ by $\$ 0.7631=\$ 3.86$

(2) 9.94 by $.7631=7.58$

(3) 4.53 by $.7631=3.46$

(4) 2.72 by $\quad .76: 31=2.07$

(1) $\$ 5.06-\$ 3.86=\$ 1.20$. Douglas fir stumpage ..................... $\$ 1.20$

(2) $\$ 9.94-\$ 7.58=\$ 2.36$, western white pine stumpage................ 2.50

(3) $\$ 4.53-\$ 3.46=\$ 1.07$, western red-cedar stumpage ......................... 1.20

(4) $\$ 2.72-\$ 2.07=\$ 0.65$, western hemlock and amabilis fir stumpage............ .50

Cedar poles.-The major portion of the cedar stand is of low quality, varying in tree sizes from small poles up to 5 feet in diameter. It appears that there is, on the lower elevations, small redar timber that is more raluable for poles and piling than for sawtimber. While no detailed estimate was made of the percentages of sizes, the number of each length and size as set out below is the result of several acre estimates taken at random.

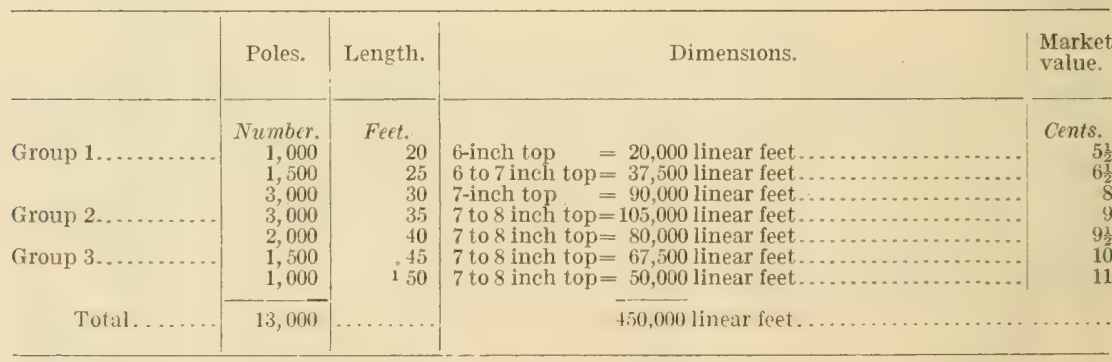

1 And up.

13,000 poles, average length 35 ieet, representing approximately 800,000 feet log scale.

Average values.-Group 1, $\$ 0.0755$ per linear foot $=\$ 0.075$; group 2, $\$ 0.0927$ per linear foot $=\$ 0.090$; group $3, \$ 0.1042$ per linear foot $=\$ 0.105$.

Pole costs.- (utting and peeling. \$0.0125; skidding and decking, s0.0275; loading and railroad haul to Dee, $\$ 0.0075$; reloading at Dee for final shipment, $\$ 0.0075$; general expense, $\$ 0.0050 ; \$ 0.06$ per linear foot for 40 feet and under; one-half cent higher for 45 feet and up.

\begin{tabular}{|c|c|c|c|c|c|c|}
\hline & Value. & Per cent. & Cost. & Margin. & Profit. & $\begin{array}{l}\text { Stump- } \\
\text { age. }\end{array}$ \\
\hline $\begin{array}{l}\text { Group } 1 \ldots \\
\text { Group } 2 \ldots \\
\text { Group } 2 \ldots\end{array}$ & $\begin{array}{r}\$ 0.075 \\
.090 \\
.105\end{array}$ & $\begin{array}{l}33 \\
41 \\
26\end{array}$ & $\begin{array}{c}\$ 0.06 \\
.06 \\
.065\end{array}$ & $\begin{array}{r}\$ 0.015 \\
.030 \\
.040\end{array}$ & $\begin{array}{r}\$ 0.01 \\
.01 \\
.01\end{array}$ & $\begin{array}{r}\$ 0.005 \\
.020 \\
.030\end{array}$ \\
\hline
\end{tabular}

Average stumpage price for 450,000 linear feet, $\$ 0.01765$; total value, $\$ 7,942.50$. 
The selling prices per linear foot are the most relable that could be obtained for the years of 1914-15, and three months of 1916 .

Applicant.-The applicant J. IV. Palmer, of Hood River, Oreg., was engaged in the milling husiness at Blaine, Wash., several years ago. Mr. Palmer has had a wide experience in lumber manufacture and selling in Minnesota and the south. He is at present living on his ranch near Hood River. He stated that he and his associates have an option to lease or purchase the Oregon Lumber Co.'s mill at Dee, Oreg., but have not decided which they will do, but in all probability they will buy the plant. In conference with the applicant, Mr. West, general manager of the mill at Dee, has either been present or his name brought into the conversation. Mr. West has made the surveys for the railroad by which the timber will be tapped.

Fire lines.-A fire line should be constructed around the exterior boundaries of the sale, these lines to be ronstrueted as logring progresses, and should be built in accordance with contract specifications. All dead trees should be felled as logging progresses.

Administrution.-The sale should be in charge of a man who has had experience in scaling and sale administration. The manner in which the timber will be opened up will determine the number of scalers required; if the cut is concentrated so that the varders are working close to each other, one man can handle the scaling, ot herwise two will be necessary. The Oregon Forest has not a man at present that could be assigned to sraling or administration. Provisions should be made for increasing the force by two men.

ILanagement.- Provisions for reforesting the cutover area by the methods of broadcast slash burning and reseeding by the reservation and preservation of virgin areas and single totally defective and other trees is not as simple as in most louglas fir types. The most serious factors in leaving seed trees or groups of seed trees in the nature stand are that, first, the timber in the Douglas fir type is tall and of scanty crown, making it very susceptible of windthrow, aside from being very poor for producing a satisfactory volume of seed. Again, selection of seed groups on points and ridges, where the timber is short and reasonably sale from windthrow, the stand is, in most instances, made up of thirty to fifty per cent of hemlock.

It is not believed that there is a sufficient quantity of totally defective trees for reseeding the area. There is, however, a fair number of veteran, wolf trees that will not qualify as merchantable. These trees occur mostly around the edges of rock slides, but many are found here and there throughout the area.

The stand outside the sale boundary is made up of a stunted growth of hemlock, Douglas fir, amabilis fir, and noble fir.

It is believed that the best plan to follow would be to reserve areas on points and ridges where the timber is reasonably safe from windthrow, protect all unmerchantable green trees, and reserve in some cases partially defective or other single trees that would be safe from windthrow. These three safeguards together with the stand outside the ale boundary will be suflicient to reseed the area in case the reproduction that will naturally follow the slash burning is ever destroyed.

The water flow is an important factor in this region since there are large areas in both what is locally designated as upper and lower Hood River Valley dependent upon irrigation for the successinl raising of tree fruits and berry crops. "It is not believed that the removal of the Government timber will in any way affect the stream flow. The opinion is based upon two factors: (1) approximately 50 per cent of the drainage area will not be logged. This area supports a tairly heavy stand of unmerchantable timber, practically all of which is located on the heads of the sereral streams forming the main river. (2) Ladd ('reek, the principal tributary of the West Fork of Hood River is a glacial stream. Also, McGee has its sourre near the perpetual snow beds of Mount Hood.

IV. T. ANdrews, Logging Engineer.

\section{A. NeLson, Lumberman.}

Mr. Greeley. I might leave with the committee, for examination by members of the committee, a complete set of maps, estimate details, and valuation appraisals on a watershed in Idaho. They will give the entire record from the start, including the estimates, topographic maps, and the method of arriving at the value of the stumpage. 


\section{STATEMENT OF HON. C. N. McARTHUR, A REPRESENTATIVE FROM THE STATE OF OREGON.}

Mr. McArtion. Mr. Chairman and gentlemen of the conmittee, this measure is of great importance to the city of Portland, which is located in the congressional district which I have the honor to represent. Portland is a great eity of nearly 300,000 inhabitants and has gone to considerable expense to provide itself with a wholesome and bountiful supply of pure mountain water. "This water is taken from Bull Run, a stream situate in that portion of the Oregon National Forest, which was formerly known as the Bull Run Forest Reserve, and which was set aside by Executive proclamation a number of year's ago. 'The intake for the city water supply is approximately 30 miles east of Portland, the water being piped from this intake to the city's reservoirs. The Bull Run Forest Reserve, which includes more than six townships, is situate in the eastern end of Multnomah County and in the northeastern corner of Clackamas County. The actual Bull Run watershed is considerably smaller in area than the reserve, but it has been thought best to include the areas outside the watershed within the limits of the reserve as the growth of the city will, within a few years, require more water than can be obtained from Bull Run, so it will be necessary to tap some of the streams that flow in other directions from the summit of the watershed. The question of maintaining our water supply is vitally affected by this bill for the reason that there are approximately 8,000 acres of privately owned land within the reserve at the present time. It is true that only a small portion of this 8,000 acres actually lies within the Bull Ruin watershed, but there is nevertheless a strong desire on the part of the residents of Portland that all of this 8,000 acres be acquired by the Government and maintained in perpetual public ownership. The major portion of this 8,000 acres of land is owned by various lumbering and logging companies, the principal owner boing the Bridal Veil Lumbering Co. Thus far the operations of this company have not seriously affected the water supply of the city and the company has shown its willingness to deed over to the Govermment its loggedoff land areas within the reserve.

The Govermment at present owns a considerable amount of timber land within the reserve, but without the limits of the watershed, while the Bridal Veil Lumbering Co. owns other timber lands of equal value within the watershed. Officials of this company have conferred with the water commissioner of the city of Portland and with representatives of the Forestry Service, and have agreed upon certain exchanges which will enable the Government to take over lands within the watershed in exchange for lands ourside the watershed upon the basis of equal value. The only obstacle in the way of the consummation of this exchange is the one of legal authority, and it is for this reason that the bill in question is being pressed at this time. The bill vests in the Secretary of Agriculture-the governing authority of the Forest Service - the right to make such exchanges as he may deem proper and in accordance with the public welfare. I feel quite certain that no man oceupying this position would ever abuse the trust imposed in him by exchanging raluable timber lands for lands of less value and, therefore, feel that there is no way by which the public could be swindled or defrauded by the 
passage of this bill. On the other hand, I regard it as imperative that some measure of this kind be enacted in order that there be no further logging operations, or no settloment of any character within the Bull Rum watershed. These logering operations and the sewage and refuse which naturally follow in the wake of settlement would, in time, pollute the purity of our water which is second to none in the Enited States. We desire to maintain not only the purity, but the suffieiency of this water supply, but it is a well-kmown fart that if land is once logged, the supply of water will not be as great as if it were left in its natural state. "The presence of treses on a watershed tend to preserve the snow fall of the winters and equalize the distribution of water. When an area has been denuded by logerine operations, the winter snoms melt rapially upon the approach of summer weather and flood conditions ensue. 'The promise of the Bridal Yeil Lumbering C'o. to deed over to the Goverment its logered off lands means that these lands can be reforested and that within a few years there will be an abundant coreling of second growth timber which will, in a measure, protect the headraters of the small streams flowing into Bull Run.

In addition to the $\$, 000$ itcres of privatcly owned land within the Bull Run Forest Reserve, there are apploximately 11,360 of Oregon e California Railioal grant lands included within the exterior limits. These lands are withheld from settlement for two years by rirtue of the Oregon and California land grant bill, recently signed by the President, but I am preparing a cenceal bill providing that they be taken over by the Government and maintained in public ownership.

There has been an effort on the part of speculators and their representatives to acquire these and other public: lands in the Oregon and California grant for selfish purposes, but I am confident that C'ongress will take the necessary action to protect public interests in this matter.

The pending bill is of great importanee to the people of the eity of Portland, and I trust that you will give it your favorable consideration and report it out at an early date. The Forestry Serrece is heartily in favor of this measure and, while it is apparentiy local in character, it is of great importance in that it affects the health and happiness of the people of one of our great cities. I do not know of any local bill that has come before this Congress that is of such great concern as the one now before you.

(Thereupon the committee procected to the consideration of executive business.) 



Gaylord Bros.

Makers

Syracuse, N. Y.

PAT. JAN. 21, 1908 
LIBRARY OF CONGRESS

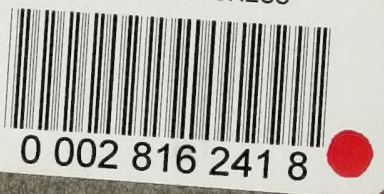

